\title{
Temporal Behavior of Tree Communities in Different Soil Classes
}

\author{
Alisson Borges Miranda Santos ${ }^{1}$ (D), Warley Augusto Caldas Carvalho ${ }^{1}$ (D), \\ Jean Daniel Morel ${ }^{1}$ (1), Rubens Manoel dos Santos ${ }^{1}$ (1), \\ Maria Auxiliadora Pereira Figueiredo ${ }^{1}$ (D), \\ Tainá Mamede Cirne-Silva ${ }^{1} \mathbb{B}$, Cléber Rodrigo de Souza ${ }^{1}$ \\ ${ }^{1}$ Universidade Federal de Lavras (UFLA), Lavras, MG, Brasil
}

\begin{abstract}
The objective of this work was to evaluate if the soil heterogeneity expressed by the different soil classes would condition tree communities with different dynamic behaviors. The data were collected from 25 plots sized $20 \times 20\left(400 \mathrm{~m}^{2}\right), 10$ of them with Inceptisols, 9 with Ultisols, 5 with Entisols B and 1 with Entisols A. All individuals with DBH $\geq 5.0 \mathrm{~cm}$ in the plots were sampled in 2000, 2005, 2009 and 2015. Rates of mortality, recruitment, gain, loss and turnover dynamics in number of individuals and basal area were estimated for each soil class. The tree communities present in the soil classes showed no differences in the dynamic behavior to the point of expressing edaphic fragment heterogeneity. The differences are associated with stochastic fluctuations in rates caused by small disturbances, suggesting little influence of the soils on the dynamics of small-scale communities.
\end{abstract}

Keywords: forest dynamics, soil heterogeneity, dynamics rates. 


\section{INTRODUCTION AND OBJECTIVES}

Tropical forests are dynamic systems that exhibit variations throughout space and time. In semi-deciduous forests, this variation has been associated with a history of fragment disturbance and environmental heterogeneity caused by water availability, topography, successional stages and soil types (Botrel et al., 2002; Meyer et al., 2015; Morel et al. 2016; Oliveira-Filho et al., 2007; Terra et al., 2015).

Among the factors that promote environmental heterogeneity, soil stands out as one of the main determinants of tropical forests on local scales. On this scale, the specific characteristics of each habitat assume a special role in conditioning vegetation. The abundance and distribution of tree individuals, the richness and diversity of species and the tropical forest's structure are strongly influenced by soil resource availability (nutrients and water) on small scales (Bolhman et al., 2008; Martins et al., 2015; Peña-Claros et al., 2012).

Variations in soil characteristics may also cause differences in the tree community's dynamics. Growth, mortality and recruitment rates are commonly higher in environments with higher resource availability, such as fertility and humidity, resulting in faster turnover rates (Martins et al., 2015; Missio et al., 2016; Pontara et al., 2016; Russo et al., 2008), while slow growth, low mortality and recruitment of individuals are observed in poor-resourced soils (Martins et al., 2015; Missio et al., 2016; Pontara et al., 2016; Russo et al., 2008).

In this sense, our study aims to analyze the dynamic behavior of a semi-deciduous seasonal forest with different soil types after 15 years of monitoring. Therefore, we hypothesized that soil heterogeneity, expressed by different soil classes, conditions tree communities with different dynamic behaviors.

\section{MATERIALS AND METHODS}

\subsection{Study area}

The study area comprises a fragment of Seasonal Semi-deciduous Forest located on the riverbanks of Ingaí River, municipality of Ingaí, in the Alto Rio Grande region of southern Minas Gerais, and at the geographical coordinates $21^{\circ} 24^{\prime} \mathrm{S}$ and $44^{\circ} 55^{\prime} \mathrm{W}$. The fragment has a total area of $16.85 \mathrm{ha}$, with an altitude varying between 870 and $890 \mathrm{~m}$ (Botrel et al., 2002).
The study area has no cutting history, only the removal of some trees at the edge of the forest in the 1950s (Botrel et al., 2002), and presence of domestic animals, such as cattle and horses, which were very common until 2009. Currently, only some trails, which may exist due to the sporadic presence of these animals and visiting fishermen, have been observed in the fragment. The matrix in the fragment's surroundings is formed by other small fragments and by anthropized areas (pastures and eucalyptus, among others).

According to the Köppen classification, the climate of the region is Cwa; a subtropical climate with dry winter and rainy summer (Dantas et al., 2007). The average annual temperature is $20^{\circ} \mathrm{C}$, with maximum average of $28.1^{\circ} \mathrm{C}$ and minimum of $9.3^{\circ} \mathrm{C}$; the average annual rainfall corresponds to $1476 \mathrm{~mm}$ (Oliveira-Filho, 2010).

\subsection{Edaphic fragment characterization}

The forest fragment features four soil types: Gleico Eutrophic Tb Fluvent Entisols (Entisols A); Typic psamitic Fluvent Entisols (Entisols B); Typic Tb Dystrophic Haplic Cambisols (Inceptisols); and Typic haplortox soil (Ultisols) (Botrel et al., 2002). Entisol A was sampled from only 1 plot, located on the lower alluvial terraces, in which the soil remains saturated or flooded for a longer period of the year (poorly drained) and with medium texture. Entisol B was sampled from 5 plots, being present in higher alluvial terraces with occasional floods and with sandy and poorly-drained texture. Inceptisols occurred in 10 plots above the alluvial terraces or adjacent to the river, where the margin is steeper. It has medium to clayey texture and drainage ranging from imperfect to moderately drained. Ultisol was sampled from 9 plots in higher areas further from the river. This soil has medium texture and drainage ranging from well to markedly drained. The variations in soil type, fertility, humidity and relief suggest the presence of a gradient: Ultisols $<$ Inceptisols $<$ Entisols $\mathrm{B}<$ Entisols A; which corresponds to an increase in water and nutrient availability (Botrel et al., 2002).

\subsection{Monitoring the tree community}

The first study of the tree community was conducted between August 1999 and August 2000, when 25 permanent $20 \times 20 \mathrm{~m}$ plots were allocated, totaling 1 ha of sampled area. The layout of the plots is detailed 
in Botrel et al. (2002). All tree individuals in the plots with DBH (diameter at breast height) $\geq 5.0 \mathrm{~cm}$ were sampled, received numbered aluminum plates and were identified (Botrel et al., 2002). Individuals with multiple stems were recorded when the quadratic root of the DBH was $\geq 5.0 \mathrm{~cm}$ (Scolforo \& Mello, 2006). The plots were measured again in the years 2005, 2009 and 2015, with the objective of re-measuring the surviving individuals, estimating dead individuals and including those that met the minimum inclusion criterion.

\subsection{Tree community dynamics by soil class}

The tree community dynamics were analyzed for each soil class according to the rates of: Equation 1 (mortality of individuals) and Equation 2 (recruitment of individuals); Equation 3 (basal area loss); and Equation 4 (basal area gain). These formulas were obtained according to Sheil et al. (1995) and Sheil \& May (1996):

$$
\begin{aligned}
& \mathrm{M}=\left\{1-\left[\frac{\mathrm{N}_{0}-\mathrm{N}_{\mathrm{m}}}{\mathrm{N}_{0}}\right]^{\frac{1}{\mathrm{t}}}\right\} \times 100 \\
& \mathrm{R}=\left\{1-\left[1-\left(\frac{N_{r}}{N_{t}}\right)^{\frac{1}{\mathrm{t}}}\right\} \times 100\right. \\
& \mathrm{L}=\left\{1-\left[\frac{\mathrm{BA}_{0}-\left(\mathrm{BA}_{\mathrm{d}}+\mathrm{BA}_{\mathrm{m}}\right)}{\mathrm{Ab}_{0}}\right)^{\frac{1}{\mathrm{t}}}\right\} \times 100 \\
& G=\left\{1-\left[1-\left(\frac{B A_{r}+B A_{g}}{B A_{t}}\right)\right]^{\frac{1}{\mathrm{t}}}\right\} \times 100
\end{aligned}
$$

The turnover rates in number of trees (Equation 5) and in terms of basal area (Equation 6) were determined from the formulas described by Phillips (1996) and Phillips \& Gentry (1994):

$$
\begin{aligned}
& \mathrm{T}_{\mathrm{N}}=\left[\frac{(\mathrm{M}+\mathrm{R})}{2}\right] \\
& \mathrm{T}_{\mathrm{BA}}=\left[\frac{(\mathrm{L}+\mathrm{G})}{2}\right]
\end{aligned}
$$

In the equations, $\mathrm{N}_{0}, \mathrm{~N}_{\mathrm{t}}, \mathrm{N}_{\mathrm{m}}$ and $\mathrm{N}_{\mathrm{r}}$ represent the numbers of initial, final, dead and recruited tree individuals in time interval $(t)$, respectively, while $\mathrm{BA}_{0}, \mathrm{BA}_{\mathrm{t}}, \mathrm{BA}_{\mathrm{m}}, \mathrm{BA}_{\mathrm{d}}, \mathrm{BA}_{\mathrm{r}}$ and $\mathrm{BA}_{\mathrm{g}}$ represent the initial alive, final alive and dead basal areas of the trees, the basal area lost with the decrease in survivors, the basal area of the recruits and the basal area gained with the increase in survivors, respectively.

The tree individuals' mortality and recruitment rates were corrected according to Lewis et al. (2004) (Equation 7) due to time irregularities between the sampling periods:

$$
\begin{aligned}
& \lambda^{\prime}=\lambda \times t^{0.08} \\
& \lambda^{\prime}: \text { corrected dynamic rates; } \lambda \text { : verified dynamic rates. }
\end{aligned}
$$

\subsection{Statistical analyses}

The data had their normality verified by the Shapiro-Wilk test (Zar, 2010). Structural and dynamic parameters were analyzed to verify differences within the soil classes between the studied time periods (2000-2005; 2005-2009 and 2009-2015), and the space between the soil classes at each monitoring interval. In the temporal comparisons, the parameters of basal area and abundance of individuals were compared using the paired T-test at a significance level of 5\% (Zar, 2010), while for the spatial comparisons, the basal area and abundance of individuals were compared by the analysis of variance (ANOVA) followed by Tukey's test at a significance level of 5\%. The changes over time and between soil classes in relation to the number of dead, recruits, losses (baseline area of the deceased individuals plus the decrease in survivors) and gains (baseline area of the recruits plus the increase in survivors) were verified using the non-parametric Kruskal-Wallis test with the Mann-Whitney test, considering a significance level of $5 \%$ (Zar, 2010). The turnover in numbers of individuals and in basal area were compared over time and between the soil classes also by the analysis of variance (ANOVA) followed by Tukey's test at a significance level of 5\%. To meet the statistical assumptions, the turnover rates were transformed by the equation "arcsen $=\operatorname{root}(\times / 100)$ " (Zar, 2010). The Entisols A class was removed from the temporal comparisons and from the comparisons between environments since it did not feature repetitions, and thus was analyzed and discussed separately. The statistical analyses were performed using the PAST v.3.14 software (Hammer et al., 2001). 


\section{RESULTS AND DISCUSSION}

The abundance of individuals showed a trend of decreasing over time in the classes of Ultisols, Inceptisols and Entisols B, especially in the interval between 2009 and 2015 , when the number of individuals was significantly lower in each of these classes in the year 2015. In the comparisons between them, the abundance of individuals was significantly higher in Ultisols in the four studies, Entisols B having featured an abundance of individuals that was similar to that shown by Ultisols in 2009 (Table 1).

The number of deaths in Ultisols and Entisols B was significantly higher in the third interval, resulting in rates of 2.93 and $6.65 \%$ year $^{-1}$, respectively. The mortality in Ultisols was also significant in the second interval $\left(2.97 \%\right.$.year $\left.{ }^{-1}\right)$. Nonetheless, the comparisons between soil classes did not show significant differences in the number of deaths for any of the monitoring intervals (Table 1).

The recruitment of individuals showed no temporal differences in any soil class, and they also did not differ from one another (Table 1). The turnover in number of individuals showed temporal differences in Ultisols, where the second interval had a significantly lower turnover rate; and in Entisols B, with the turnover rate of 2009-2015 having been higher than that of 2005-2009. In the comparisons between classes, the environments differed in the third interval, the turnover in number of individuals having been faster in Inceptisols and Entisols B (Table 1).

As for the biomass descriptors, basal area showed a significant increase between 2000 and 2005 and from 2005 to 2009 in the soil classes of Ultisols, Inceptisols and Entisols B. However, no significant differences in basal area in the period between 2009 and 2015 were found for any soil class. The basal area was significantly higher in Entisols B in 2005, and no other significant differences were found between soils for the other years of monitoring (Table 1).

The loss in basal area was significantly higher for the third interval in Ultisols, resulting in a rate of $1.97 \%$.year ${ }^{1}$, and in Entisols B, with a rate of $3.62 \%$.year ${ }^{-1}$. In the comparisons between classes, differences were observed between 2000 and 2005, when the loss was lower in Ultisols, and between 2009 and 2015, when it was higher in Entisols B (Table 1).

The basal area gains showed no differences over the monitoring periods for any soil class (Table 1). Among the environments, differences were verified only in the first interval, in which Entisols B had a superior gain in basal area. The basal area turnover was significantly higher in the second interval of Ultisols. Differences in classes were observed between 2005 and 2009, the fastest turnover in basal area having been found in Ultisols; and between 2009 and 2015, with Entisols B having shown a faster turnover than Inceptisols (Table 1).

Table 1. Structural parameters and dynamic rates of the arboreal communities present in the classes of Ultisols, Inceptisols and Entisols B at the Seasonal Semi-deciduous Forest fragment in the municipality of Ingaí, MG. Capital letters represent the significant statistical difference $(\mathrm{p} \leq 0.05)$ between the environments in each monitoring interval, and lowercase letters, the differences over time for each soil class.

\begin{tabular}{|c|c|c|c|c|c|c|c|c|c|c|c|c|}
\hline \multirow{2}{*}{ Rates } & \multicolumn{4}{|c|}{ Ultisols } & \multicolumn{4}{|c|}{ Inceptisols } & \multicolumn{4}{|c|}{ Entisols B } \\
\hline & 2000 & 2005 & 2009 & 2015 & 2000 & 2005 & 2009 & 2015 & 2000 & 2005 & 2009 & 2015 \\
\hline A & $127 \pm 19^{\mathrm{Aa}}$ & $126 \pm 19^{\mathrm{Aa}}$ & $123 \pm 22^{\mathrm{Aa}}$ & $115 \pm 20^{\mathrm{Ab}}$ & $100 \pm 18^{\mathrm{Ba}}$ & $97 \pm 18^{\mathrm{Ba}}$ & $93 \pm 20^{\mathrm{Ba}}$ & $86 \pm 20^{\mathrm{Bb}}$ & $101 \pm 23^{\mathrm{Ba}}$ & $97 \pm 20^{\mathrm{Ba}}$ & $97 \pm 18^{\mathrm{Aa}}$ & $77 \pm 20^{\mathrm{Bb}}$ \\
\hline $\mathrm{BA}$ & $0.95 \pm 0.32^{\mathrm{Aa}}$ & $1.08 \pm 0.34^{\mathrm{Ab}}$ & $1.18 \pm 0.36^{\mathrm{Ac}}$ & $1.26 \pm 0.33^{\mathrm{Ac}}$ & $1.24 \pm 0.32^{\mathrm{Aa}}$ & $1.31 \pm 0.29^{\mathrm{Ab}}$ & $1.37 \pm 0.29^{\mathrm{Ac}}$ & $1.37 \pm 0.31^{\mathrm{Ac}}$ & $1.33 \pm 0.10^{\mathrm{Aa}}$ & $1.46 \pm 0.10^{\mathrm{Bb}}$ & $1.57 \pm 0.12^{\mathrm{Ac}}$ & $1.42 \pm 0.15^{\mathrm{Ac}}$ \\
\hline M & - & 1.60 & 2.97 & 2.93 & - & 2.38 & 3.39 & 3.44 & - & 2.78 & 2.25 & 6.65 \\
\hline $\mathrm{R}$ & - & 1.44 & 2.19 & 1.68 & - & 1.72 & 2.44 & 1.87 & - & 1.93 & 2.08 & 2.37 \\
\hline $\mathrm{L}$ & - & 1.34 & 2.28 & 1.97 & - & 1.93 & 2.21 & 2.10 & - & 2.03 & 1.86 & 4.12 \\
\hline G & - & 3.80 & 4.52 & 2.97 & - & 2.99 & 3.35 & 2.07 & - & 3.84 & 3.62 & 2.54 \\
\hline$T_{n}$ & - & $1.52^{\mathrm{Aa}}$ & $2.58^{\mathrm{Ab}}$ & $2.30^{\mathrm{Aa}}$ & - & $2.05^{\mathrm{Aa}}$ & $2.91^{\mathrm{Aa}}$ & $2.65^{\mathrm{Ba}}$ & - & $2.35^{\mathrm{Aab}}$ & $2.16^{\mathrm{Aa}}$ & $4.51^{\mathrm{Bb}}$ \\
\hline $\mathrm{T}_{\mathrm{ba}}$ & - & $2.57^{\mathrm{Aa}}$ & $3.40^{\mathrm{Ab}}$ & $2.47^{\mathrm{Aba}}$ & - & $2.46^{\mathrm{Aa}}$ & $2.78^{\mathrm{Ba}}$ & $2.08^{\mathrm{Aba}}$ & - & $2.93^{\mathrm{Aa}}$ & $2.74^{\mathrm{Ba}}$ & $3.33^{\mathrm{Ba}}$ \\
\hline $\mathrm{Nm}$ & - & $9 \pm 3^{\mathrm{Aa}}$ & $13 \pm 4^{\mathrm{Ab}}$ & $18 \pm 7^{\mathrm{Ab}}$ & - & $10 \pm 5^{\mathrm{Aa}}$ & $11 \pm 4^{\mathrm{Aa}}$ & $16 \pm 0.03^{\mathrm{Aa}}$ & - & $12 \pm 6^{\mathrm{Aa}}$ & $8 \pm 6^{\mathrm{Aa}}$ & $29 \pm 13^{\mathrm{Ab}}$ \\
\hline
\end{tabular}


Table 1. Continued...

\begin{tabular}{|c|c|c|c|c|c|c|c|c|c|c|c|c|}
\hline \multirow{2}{*}{ Rates - } & \multicolumn{4}{|c|}{ Ultisols } & \multicolumn{4}{|c|}{ Inceptisols } & \multicolumn{4}{|c|}{ Entisols B } \\
\hline & 2000 & 2005 & 2009 & 2015 & 2000 & 2005 & 2009 & 2015 & 2000 & 2005 & 2009 & 2015 \\
\hline $\mathrm{Nr}$ & - & $8 \pm 5^{\mathrm{Aa}}$ & $9 \pm 6^{\text {Aa }}$ & $10 \pm 6^{\mathrm{Aa}}$ & - & $7 \pm 3^{\mathrm{Aa}}$ & $8 \pm 4^{\mathrm{Aa}}$ & $8 \pm 3^{\mathrm{Aa}}$ & - & $8 \pm 4^{\text {Aa }}$ & $7 \pm 3^{\mathrm{Aa}}$ & $9 \pm 4^{\mathrm{Aa}}$ \\
\hline $\mathrm{L}_{\mathrm{ba}}$ & - & $0.06 \pm 0.03^{\mathrm{Aa}}$ & $0.10 \pm 0.04^{\mathrm{Aa}}$ & $0.21 \pm 0.05^{\mathrm{Ab}}$ & - & $0.12 \pm 0.06^{\mathrm{Ba}}$ & $0.11 \pm 0.05^{\mathrm{Aa}}$ & $0.16 \pm 0.08^{\mathrm{Aa}}$ & - & $0.26 \pm 0.04^{\mathrm{Ba}}$ & $0.11 \pm 0.05^{\text {Aa }}$ & $0.35 \pm 0.12^{\mathrm{Bb}}$ \\
\hline $\mathrm{G}_{\mathrm{ba}}$ & - & $0.19 \pm 0.06^{\mathrm{Aa}}$ & $0.19 \pm 0.05^{\mathrm{Aa}}$ & $0.13 \pm 0.06^{\mathrm{Aa}}$ & - & $0.18 \pm 0.04^{\mathrm{Aa}}$ & $0.17 \pm 0.06^{\mathrm{Aa}}$ & $0.16 \pm 0.03^{\mathrm{Aa}}$ & - & $0.13 \pm 0.06^{\mathrm{Ba}}$ & $0.22 \pm 0.03^{\mathrm{Aa}}$ & $0.20 \pm 0.04^{\mathrm{Aa}}$ \\
\hline
\end{tabular}

2000, 2005, 2009 and 2015: years of vegetation monitoring; A: Mean abundance of individuals; BA: Mean basal area (m²); M: Mortality rate (\%.year $\left.{ }^{-1}\right)$; R: Recruitment rate $\left(\%\right.$.year $\left.{ }^{-1}\right)$; L: Loss rate $\left(\%\right.$.year $\left.{ }^{-1}\right) ;$ G: Gain rate $\left(\%\right.$.year $\left.{ }^{-1}\right) ; \mathrm{T}_{\text {ni }}$ : turnover in number of individuals $\left(\% . y e a r^{-1}\right)$; $\mathrm{T}_{\mathrm{ba}}$ : turnover in number of basal area (\%.year $\left.{ }^{-1}\right) ; \mathrm{Nm}$ : Mean number of deaths; Nr: Average number of recruits; $\mathrm{L}_{\mathrm{b}}: \mathrm{Mean}_{\mathrm{n}}$ basal area loss (decrease in survivors + basal area of deaths in $\mathrm{m}^{2}$ ); $\mathrm{G}_{\mathrm{ba}}$ : Mean basal area gain (increase in survivors + basal area of recruits in $\mathrm{m}^{2}$ ).

The only sample of Entisols A was characterized by high dynamic rates. In the first interval, the high rates were associated with the mortality of individuals and losses in basal area (20.09 and $20.60 \%$.year ${ }^{-1}$, respectively). In the second interval, the processes were reversed, with a high recruitment of individuals and gains in basal area (19.73 and $21.35 \%$.year ${ }^{-1}$, respectively), while in the third period, the demographic rates were low, but the basal area gain remained high (7.91\%.year ${ }^{-1}$ ) (Table 2).

Table 2. Structural parameters and dynamic rates of the arboreal community present of the Entisols A class at the Semi-deciduous Seasonal Forest fragment in the municipality of Ingaí, MG.

\begin{tabular}{ccccc} 
& \multicolumn{4}{c}{ Entisols A } \\
\cline { 2 - 5 } Rates & $\mathbf{2 0 0 0}$ & 2005 & $\mathbf{2 0 0 9}$ & $\mathbf{2 0 1 5}$ \\
\hline $\mathrm{A}$ & 37 & 28 & 53 & 55 \\
$\mathrm{BA}$ & 0.78 & 0.39 & 0.71 & 1.01 \\
$\mathrm{M}$ & - & 20.09 & 6.54 & 3.10 \\
$\mathrm{R}$ & - & 12.94 & 19.73 & 3.29 \\
$\mathrm{~L}$ & - & 20.60 & 8.74 & 2.26 \\
$\mathrm{G}$ & - & 8.91 & 21.35 & 7.91 \\
\hline $\mathrm{T}_{\mathrm{n}}$ & - & 17.41 & 14.29 & 3.45 \\
\hline $\mathrm{T}_{\mathrm{ab}}$ & - & 14.75 & 15.04 & 5.08 \\
$\mathrm{Nm}$ & - & 23 & 6 & 8 \\
\hline $\mathrm{Nr}$ & - & 14 & 31 & 10 \\
\hline $\mathrm{L}_{\mathrm{ba}}$ & - & 0.53 & 0.12 & 0.09 \\
\hline $\mathrm{G}_{\mathrm{ba}}$ & - & 0.15 & 0.44 & 0.40 \\
\hline
\end{tabular}

2000, 2005, 2009 and 2015: years of vegetation monitoring; A: Abundance of individuals; BA: Basal area $\left(\mathrm{m}^{2}\right)$; M: Mortality rate $\left(\%\right.$.year $\left.{ }^{-1}\right)$; R: Recruitment rate $\left(\%\right.$.year $\left.{ }^{-1}\right)$; L: Loss rate $\left(\%\right.$.year $\left.{ }^{-1}\right)$; G: Gain rate $\left(\%\right.$.year $\left.{ }^{-1}\right) ; \mathrm{T}_{\mathrm{ni}}$ : turnover in number of individuals $\left(\%\right.$.year $\left.{ }^{-1}\right)$; $\mathrm{T}_{\mathrm{ab}}$ : turnover in number of basal area $\left(\%\right.$ year $\left.^{-1}\right)$; Nm: Number of deaths; Nr: Number of recruits; $\mathrm{L}_{b a}$ : Basal area loss (decrease in survivors + basal area of deaths in $\mathrm{m}^{2}$ ); $\mathrm{G}_{\mathrm{ba}}$ : Basal area gain (increase in survivors + basal area of recruits in $\mathrm{m}^{2}$ ).
The tree communities in the soil classes had a similar temporal behavior characterized by the self-thinning of trees. In the communities submitted to self-thinning, mortality rates are higher than recruitment rates, which reduces the density of individuals and causes a shift in balance in favor of basal area gains, which provides an increase in or stability of the tree community's basal area (Higuchi et al., 2008; Meyer et al., 2015).

The similar temporal behavior among tree communities shows that, despite the existence of a fertility and texture gradient between the soil classes, the dynamic processes may not be conditioned by soil heterogeneity, since the observed differences do not describe any pattern associated with soil conditions. Other studies carried out on local scales have also verified similar dynamic behaviors among tree communities in different soil classes (Higuchi et al., 2008; Meyer et al., 2015; Toledo et al., 2011). The soils' influence on the forest dynamics has been mainly associated with large fertility variations on regional scales, with higher rates being verified in soils with greater resource availability (Phillips et al., 2004; Quesadas et al., 2009). However, on local scales, Toledo et al. (2011) state that soil fertility variations may have a modest effect on forest dynamics. On this scale, the reduced area favors lower heterogeneity due to the more similar physical conditions (light, water, soil, etc.) (Costa et al., 2012). On the other hand, on larger area size entails greater environmental heterogeneity (Cavender-Bares et al., 2009).

The low influence of soils on the tree community's dynamics verified on local scales (Higuchi et al., 2008; Meyer et al., 2015; Toledo et al., 2011; in the present study) indicates that the soils play a more important role in structuring these communities than in the dynamic processes that modify them. This edaphic 
heterogeneity would mainly influence the abundance and spatial distribution of the species in the plant communities (Bohlman et al., 2008; Pan et al., 2013; Peña-Claros et al., 2012), selecting the individuals that are more adapted to the environmental conditions based on the niche need of each species (Begon et al., 2007; Poulos \& Camp, 2010). The abundance and distribution of the species in the study area mainly reflect variations in water and nutrient availability (Botrel et al., 2002), demonstrating the importance of the soil in structuring this community.

On the other hand, the temporal behavior would be conditioned by agents that alter the successional advance of the forests, such as disturbances. Disturbances are events that drive changes in the forests due to resource changes (Davis \& Moritz, 2001; Denslow et al., 1998), in substrate availability or in the physical environment (Davis \& Moritz, 2001), thus reducing density and resulting in considerable losses of basal area, which opens spaces for the recruitment of individuals and recovery of biomass (Felfili, 1995; Chazdon et al., 2007; Sheil et al., 2000; Swanson et al., 2011). However, the absence of major disturbances that would promote the resumption of forest succession attenuates the role of soils in the studied fragment, since they would act to select the species with colonization potential in each environment. In tropical forests, the onset of succession is not stochastic, but rather conditioned by processes, such as plant-plant facilitation interactions, and local environmental conditions, such as soil characteristics, which determine the successional process in these forests (Lebrija-Trejos et al., 2010; Martins et al. 2015).

The absence of major disturbances associated with the the fragment's protection favors the successional advance of the tree communities standing over the soil classes. Seasonal tropical forests usually exhibit structural parameters of advanced successional stages around $40-45$ years after the area's abandonment, when the late colonizing species, which grow at a slower pace, become dominant or reach significant development rates (Aide et al., 1996; Lebrija-Trejos et al., 2010; Morel et al., 2016; Toniato \& Oliveira-Filho, 2004). The advanced successional stage of the tree communities in the fragment shows that they are already structured with the species that compose them and already adapted to the local environmental conditions, being dominated by species with long life cycles that have remained in the community for a long time in the absence of great disturbances, thereby attenuating the role of the soils in the selection of species. Thus, the differences among soil classes may be associated with stochastic fluctuations in dynamic rates (Carvalho \& Felfili, 2011), which are caused by small localized disturbances originated from natural disturbances, such as seasonal flooding in plots near the river bank (Silva et al., 2011).

River banks are environments characterized as dynamic due to the influence of a number of factors that alter their configuration and the patterns of plant communities (Kyle \& Leishman, 2009). One of these factors is the river water's action on the slope's concave margin, which promotes the continuous removal of sediments (Christofoletti, 1980). In Entisols B, this action resulted in the collapse of part of a plot between 2009 and 2015, and in the death of several tree individuals. Another factor is the occurrence of seasonal floods caused by the overflow of the riverbed and/or elevation of the water levels during periods of intense precipitation (Almeida Júnior et al., 2009; Carvalho et al., 2007). Seasonal flooding represents an important disturbance that changes the dynamics of Entisols A. Floods increase the mortality of individuals and the loss of basal area (Niu et al., 2014; Silva et al., 2011), thus making room for the recruitment of individuals (Felfili, 1995) and causing instability in the dynamics of forests bordering water courses.

\section{CONCLUSIONS}

The tree communities did not show differences in dynamic behavior to the point of expressing edaphic fragment heterogeneity. The differences found are probably more associated with stochastic fluctuations caused by minor disturbances, suggesting lesser influence of the soils on the dynamics of communities on small scales. On this scale, soils may play a more important role in structuring the community, influencing parameters such as the abundance and distribution of species. However, in this fragment, this influence may be attenuated by the advanced stage of succession and the absence of major disturbances.

\section{SUBMISSION STATUS}

Received: 10 July, 2017

Accepted: 22 Dec., 2017 


\section{CORRESPONDENCE TO}

\section{Alisson Borges Miranda Santos}

Universidade Federal de Lavras (UFLA), Departamento de Ciências Florestais, Av. Doutor Sylvio Menicucci, 1.001, CEP 37200-000, Lavras, MG, Brasil e-mail: alissonborges@globomail.com

\section{REFERENCES}

Aide TM, Zimmermman JK, Rosario M, Marcano-Vega $\mathrm{H}$. Forest recovery in abandoned cattle pastures along an elevational gradient in northeastern Puerto Rico. Biotropica 1996; 28(4): 537-548. 10.2307/2389095

Almeida Júnior EBD, Olivo MA, Araújo EDL, Zickel CS. Caracterização da vegetação de restinga da RPPN de Maracaípe, PE, Brasil, com base na fisionomia, flora, nutrientes do solo e lençol freático. Acta Botanica Brasilica 2009; 23(1): 36-48. 10.1590/S0102-33062009000100005

Begon M, Townsend CR, Harper JL. Ecologia: de indivíduos a ecossistemas. 4th ed. Porto Alegre: Artmed; 2007.

Bohlman SA, Laurance WF, Laurance SG, Nascimento HE, Fearnside PM, Andrade A. Importance of soils, topography and geographic distance in structuring central Amazonian tree communities. Journal of Vegetation Science 2008; 19(6): 863-874. 10.3170/2008-8-18463

Botrel RT, Oliveira-Filho AD, Rodrigues LA, Curi N. Influência do solo e topografia sobre as variações da composição florística e estrutura da comunidade arbóreoarbustiva de uma floresta estacional semidecidual em Ingaí, MG. Revista Brasileira de Botânica 2002; 25(2): 195-213. 10.1590/S0100-84042002000200008.

Carvalho CS, Macedo ES, Ogura AT. Mapeamento de riscos em encostas e margem de rios. Brasília: Ministério das Cidades; IPT; 2007. [cited 2017 Nov. 1). Available from: https://bit.ly/2RVZuns

Carvalho FA, Felfili JM. Variações temporais na comunidade arbórea de uma floresta decidual sobre afloramentos calcários no Brasil Central: composição, estrutura e diversidade florística. Acta Botanica Brasilica 2011; 25(1): 203-214. 10.1590/S0102-33062011000100024

Cavender-Bares J, Kozak KH, Fine PV, Kembel SW. The merging of community ecology and phylogenetic biology. Ecology Letters 2009; 12(7): 693-715. 10.1111/ j.1461-0248.2009.01314.x

Chazdon RL, Letcher SG, Van Breugel M, MartínezRamos M, Bongers F, Finegan B. Rates of change in tree communities of secondary Neotropical forests following major disturbances. Philosophical Transactions of the Royal Society B: Biological Sciences 2007; 362(1478): 273-289. 10.1098/rstb.2006.1990
Christofoletti A. Geomorfologia. São Paulo: Edgard Blucher; 1980.

Costa TL, Nascimento DM, Lins ACB. Estrutura e dinâmica da vegetação em um remanescente de Floresta Atlântica/Nordeste, Brasil. Revista Brasileira de Ciências Agrárias 2012; 7(3): 493-501. 10.5039/agraria.v7i3a1402

Dantas AAA, Carvalho LG, Ferreira E. Climatic classification and tendencies in Lavras region, MG. Ciência e Agrotecnologia 2007; 31(6): 1862-1866. 10.1590/S1413-70542007000600039

Davis FW, Moritz M. Disturbance, mechanisms of. In: Levin SA. Encyclopedia of biodiversity. Cambridge: Academic Press; 2001.

Denslow JS, Ellison AM, Sanford RE. Treefall gap size effects on above-and below-ground processes in a tropical wet forest. Journal of Ecology 1998; 86(4): 597-609. 10.1046/j.1365-2745.1998.00295.x

Felfili JM. Growth, recruitment and mortality in the Gama gallery forest in central Brazil over a six-year period (19851991). Journal of Tropical Ecology 1995; 11(1): 67-83. $10.1017 /$ S0266467400008415

Hammer $\emptyset$, Harper DAT, Ryan PD. PAST: Paleontological statistics software package for education and data analysis. Palaentologia Electronica 2001 [cited 2019 July 2]; 4(1): 9. Available from: https://bit.ly/2Xp0XbU

Higuchi P, Oliveira-Filho AT, Silva ACD, Machado ELM, Santos RMD, Pifano DS. Dinâmica da comunidade arbórea em um fragmento de floresta estacional semidecidual montana em Lavras, Minas Gerais, em diferentes classes de solos. Revista Árvore 2008; 32(3): 417-426. 10.1590/ S0100-67622008000300004

Kyle G, Leishman MR. Plant functional trait variation in relation to riparian geomorphology: the importance of disturbance. Austral Ecology 2009; 34(7): 793-804. 10.1111/j.1442-9993.2009.01988.x

Lebrija-Trejos E, Meave JA, Poorter L, Pérez-García EA, Bongers F. Pathways, mechanisms and predictability of vegetation change during tropical dry forest succession. Perspectives in Plant Ecology, Evolution and Systematics 2010; 12(4): 267-275. 10.1016/j.ppees.2010.09.002

Lewis SL, Phillips OL, Sheil D, Vinceti B, Baker TR, Brown $S$ et al. Tropical forest tree mortality, recruitment and turnover rates: calculation, interpretation and comparison when census intervals vary. Journal of Ecology 2004; 92(6): 929-944. 10.1111/j.0022-0477.2004.00923.x

Martins KG, Marques MC, Santos E, Marques R. Effects of soil conditions on the diversity of tropical forests across a successional gradient. Forest Ecology and Management 2015; 349: 4-11. 10.1016/j.foreco.2015.04.018

Meyer PB, Oliveira-Filho ATD, Botezelli L, Fontes MAL, Garcia PO, Santos RMD. Dinâmica estrutural em um fragmento de floresta estacional semideciduifólia em Lavras, MG, Brasil. Cerne 2015; 21(2): 259-265. $10.1590 / 01047760201521021711$ 
Missio FDF, Higuchi P, Silva AC, Longhi SJ, Salami B, Dalla Rosa A et al. Trade-offs and spatial variation of functional traits of tree species in a subtropical forest in southern Brazil. iForest - Biogeosciences and Forestry 2016; 9(6): e1-e5. 10.3832/ifor1960-009

Morel JD, Pereira JAA, Santos RM, Machado ELM, Marques JJ. Diferenciação da vegetação arbórea de três setores de um remanescente florestal relacionado ao seu histórico de perturbações. Ciência Florestal 2016; 26(1): 81-93. 10.5902/1980509821093

Niu S, Luo Y, Li D, Cao S, Xia J, Li J et al. Plant growth and mortality under climatic extremes: an overview. Environmental and Experimental Botany 2014; 98: 1319. 10.1016/j.envexpbot.2013.10.004

Oliveira-Filho AT, Carvalho WAC, Machado EL, Higuchi P, Appolinário V, Castro GC et al. Dinâmica da comunidade e populações arbóreas da borda e interior de um remanescente florestal na Serra da Mantiqueira, Minas Gerais, em um intervalo de cinco anos (19992004). Revista Brasileira de Botânica 2007; 30(1): 149-161. 10.1590/S0100-84042007000100015

Oliveira-Filho AT. Flora arbórea da região Neotropical: um banco de dados envolvendo biogeografia, diversidade e conservação. 2010 [cited 2016 Mar. 25]. Available from: https://bit.ly/2XoLTGa

Pan Y, Birdsey RA, Phillips OL, Jackson RB. The structure, distribution, and biomass of the world's forests. Annual Review of Ecology, Evolution, and Systematics 2013; 44(1): 593-622. 10.1146/annurev-ecolsys-110512-135914

Peña-Claros M, Poorter L, Alarcón A, Blate G, Choque U, Fredericksen TS et al. Soil effects on forest structure and diversity in a moist and a Dry Tropical Forest. Biotropica 2012; 44(3): 276-283. 10.1111/j.1744-7429.2011.00813.x

Phillips OL. Long-term environmental change in tropical forests: increasing tree turnover. Environmental Conservation 1996; 23(3): 235- 246. 10.1017/S0376892900038856

Phillips OL, Baker TR, Arroyo L, Higuchi N, Killeen TJ, Laurance WF et al. Pattern and process in Amazon tree turnover, 1976-2001. Philosophical Transactions of the Royal Society B: Biological Sciences 2004; 359(1443): 381-407. 10.1098/rstb.2003.1438

Phillips OL, Gentry AH. Increasing turnover through time in tropical forests. Science 1994; 263(5149): 954-958. $10.1126 /$ science.263.5149.954

Pontara V, Bueno ML, Garcia LE, Oliveira-Filho AT, Pennington TR, Burslem DF et al. Fine-scale variation in topography and seasonality determine radial growth of an endangered tree in Brazilian Atlantic forest. Plant and Soil 2016; 403(1-2): 115-128. 10.1007/s11104-016-2795-3

Poulos HM, Camp AE. Topographic influences on vegetation mosaics and tree diversity in the Chihuahuan
Desert Borderlands. Ecology 2010; 91(4): 1140-1151. 10.1890/08-1808.1

Quesada CA, Lloyd J, Schwarz M, Baker TR, Phillips OL, Patiño $S$ et al. Regional and large-scale patterns in Amazon forest structure and function are mediated by variations in soil physical and chemical properties. Biogeosciences Discussion 2009; 6: 3993-4057. 10.5194/bg-9-2203-2012

Russo SE, Brown P, Tan S, Davies SJ. Interspecific demographic trade-offs and soil-related habitat associations of tree species along resource gradients. Journal of Ecology 2008; 96(1): 192-203. 10.1111/j.1365-2745.2007.01330.x

Scolforo JS, Mello JM. Inventário Florestal. 1. ed. Lavras: Editora UFLA; 2006.

Sheil D, Burslem DFRP, Alder D. The Interpretation and misinterpretation of mortality rate measures. Journal of Ecology 1995; 83(2): 331-333. 10.2307/2261571

Sheil D, Jennings S, Savill P. Long-term permanent plot observations of vegetation dynamics in Budongo, a Ugandan rain forest. Journal of Tropical Ecology 2000; 16(6): 785-800. 10.1017/S026646740000172

Sheil D, May RM. Mortality and recruitment rate evaluations in heterogeneous tropical forests. Journal of Ecology 1996; 84(1): 91-100. 10.2307/2261703

Silva AC, Berg E, Higuchi P, Nunes MH. Dinâmica de uma comunidade arbórea após enchente em fragmentos florestais no sul de Minas Gerais. Revista Árvore 2011; 35(4): 883-894. 10.5380/rf.v46i1.34782

Swanson ME, Franklin JF, Beschta RL, Crisafulli CM, DellaSala DA, Hutto RL et al. The forgotten stage of forest succession: early-successional ecosystems on forest sites. Frontiers in Ecology and the Environment 2011; 9(2): 117-125. 10.1890/090157

Terra MCNS, Mello JMD, Mello CRD, Santos RM, Nunes ACR, Raimundo MR. Topographical, soil and climatic influences in an Atlantic Forest remnant in Serra da Mantiqueira, Minas Gerais State. Revista Ambiente e Água 2015; 10(4): 928-942. 10.4136/ambi-agua.1705

Toledo JJ, Magnusson WE, Castilho CV, Nascimento HE. How much variation in tree mortality is predicted by soil and topography in Central Amazonia? Forest Ecology and Management, 2011;262(3): 331-338. 10.1016/ j.foreco.2011.03.039

Toniato MTZ, Oliveira-Filho AT. Variations in tree community composition and structure in a fragment of tropical semideciduous forest in southeastern Brazil related to different human disturbance histories. Forest Ecology and Management 2004; 198(3): 319-339. 10.1016/ j.foreco.2004.05.029

Zar JH. Biostatistical analysis. 5th ed. New Delhi: Pearson Education; 2010. 